\title{
The Influence of 'Say on Pay' on Excessive Executive Compensation in the UK and the US
}

\author{
Zhe Wang ${ }^{1} \&$ Yunjie $\mathrm{Wu}^{2}$ \\ ${ }^{1}$ School of Humanities, China University of Political Science and Law, Beijing, China \\ ${ }^{2}$ China Institute of World Trade Organization, University of International Business and Economics, Beijing, China \\ Correspondence: Zhe Wang, China University of Political Science and Law, No. 25 Xitucheng Lu, Haidian District, \\ Beijing 100088, China. E-mail: wangzhe941221@163.com
}

Received: July 7, 2021

Accepted: September 8, 2021

Online Published: September 18, 2021

doi:10.5539/jpl.v14n4p71

URL: https://doi.org/10.5539/jpl.v14n4p71

\begin{abstract}
Along with the separation of ownership and control in modern companies, the agency problem between shareholders and managers has become a core issue in corporate law. In recent decades, there was a trend of increasing executive compensation in many countries, which led to shareholders' dissatisfaction and social concerns about the income gap. Since directors did not effectively solve the problem of excessive executive remuneration, many countries introduced the advisory shareholder vote on the remuneration report ('Say on Pay'). It is a new mechanism that allows shareholders to vote on executive remuneration. After it was first introduced in the UK, many other countries including the US adopted 'Say on Pay' to relieve the problem of excessive executive remuneration. However, there is an ongoing debate about whether 'Say on Pay' has a meaningful influence on excessive executive compensation. Some believe that shareholder voting results lead directors to create better executive remuneration plans. Others argue that 'Say on Pay' contributes little to solving this problem. It is therefore essential to analyse the effects of 'Say on Pay' on solving the excessive executive remuneration problem in the UK and the US. This essay will analyse several arguments related to the influence of 'Say on Pay' on excessive executive compensation in order to demonstrate the reasons why 'Say on Pay' contributes little to solving the excessive executive remuneration problem in the UK and the US.
\end{abstract}

Keywords: corporate law, agency problem, the advisory shareholder vote on executive remuneration, excessive executive remuneration

\section{Introduction}

In modern companies, ownership and control are separated. As investors, shareholders are the owners of companies. The board of directors and a small group of executives are employed to take responsibility for management. Along with the separation of ownership and control, the agency problem between shareholders and managers has become a core issue in corporate law. In recent decades, there was a trend of increasing executive compensation in many countries, which led to shareholders' dissatisfaction and social concerns about the income gap. Since directors did not effectively solve the problem of excessive executive remuneration, many countries introduced the advisory shareholder vote on the remuneration report ('Say on Pay'). It is a new mechanism that allows shareholders to vote on executive remuneration. After it was first introduced in the UK, many other countries including the US adopted 'Say on Pay' to relieve the problem of excessive executive remuneration. However, there is an ongoing debate about whether 'Say on Pay' has a meaningful influence on excessive executive compensation. Some believe that shareholder voting results lead directors to create better executive remuneration plans. Others argue that 'Say on Pay' contributes little to solving this problem. It is therefore essential to analyse the effects of 'Say on Pay' on solving the excessive executive remuneration problem in the UK and the US. This essay will analyse several arguments related to the influence of 'Say on Pay' on excessive executive compensation in order to demonstrate the reasons why 'Say on Pay' contributes little to solving the excessive executive remuneration problem in the UK and the US. Following the introduction, the rest of this essay is structured as follows. The first part will focus on the gap between the growth of executive remuneration and the corresponding increase of shareholder value. The second part will discuss the reason for directors' failure to supervise the adjustment of executive compensation. The third part will introduce the development of 'Say on Pay' in the UK and US. The fourth part will emphasize four arguments related to the influence of 'Say on Pay' on excessive executive compensation. The fifth part will 
reveal some limitations in existing investigations and provide some future considerations regarding 'Say on Pay'. Finally, this essay determines whether 'Say on Pay' plays a significant role in relieving the excessive executive remuneration problem in the UK and the US.

\section{Executive Remuneration - An Agency Problem in Corporate Governance}

\subsection{The Definition of Executive Remuneration}

Executives play a senior management role in the company. Their power arises from a series of resources, including their tenure, equity ownership, position on the board and working ability. ${ }^{1}$ They provide management services for companies and receive compensation. Executive compensation is often defined as an agency problem in corporate governance and management theory. ${ }^{2}$ There are various forms of executive pay, including cash pay, bonus pay, equity-based pay, perquisites and pensions. ${ }^{3}$ The pay level of executives may vary with performance. ${ }^{4}$ Specifically, executives could be paid more if they make more contributions to the firm. On the contrary, their compensation may be reduced if the value of the firm decreases. Consequently, there is a close connection between executive remuneration and business performance.

\subsection{The Objectives of Executive Remuneration}

There are three basic objectives of executive compensation, including providing executives with the motivation to make profits for shareholders, retaining talented managers and restricting firm costs. ${ }^{5}$ These goals of executive pay have not changed for several decades. The success of companies in reaching these three objectives could be evaluated by comparing executive compensation and corresponding performance. ${ }^{6}$ Namely, the good business performance of a company reflects the increase of shareholder interests. The increase of shareholder value depends on the achievement of three objectives. Only when these three objectives are achieved can executive pay be improved.

\subsection{An Agency Problem in Corporate Governance and Management Theory}

In modern companies, ownership and control are separated. Shareholders, who are the owners of companies, provide companies with funding. Their investment is the basis of company operation. As a result, they have the right to enjoy company profits. However, shareholders are not the managers of the company. A board of directors and a small group of executives working on behalf of shareholders are responsible for company management. In other words, executives can decide how to use the funds invested by shareholders. Accordingly, an agency problem arises from this relationship between shareholders and executives, and it is regarded as a core issue in corporate law. It is argued that without a proper guarantee, executives tend to pursue their own interests instead of considering the long-term profits of companies. ${ }^{7}$ Clearly, shareholders' interests are more likely to be harmed. A good solution to address the agency problem is aligning shareholders' interests and executives' compensation by ensuring that the costs to executives of pursuing their own interests outweigh the benefits. ${ }^{8}$ Specifically, if the management of executives creates firm value and shareholders benefit from the management, the executive compensation should be improved. On the contrary, if the management of executives does not achieve shareholders' interests, their pay is not effective in achieving objectives and should be decreased.

\subsection{The Gap between the Growth of Executive Remuneration and the Corresponding Increase of Shareholder Value}

Recent research concentrating on executive remuneration has illustrated that the increase in executive pay has not led to a relative rise in company value. ${ }^{9}$ In other words, shareholders have not received corresponding profits. For example, in an analysis for Southwest Airlines, for each $1 \%$ increase in shareholder wealth, executive compensation in this company increased by $1.98 \% .^{10}$ The reason for this phenomenon is that the executive pays more attention to their compensation rather than the real benefits to firms and shareholders. ${ }^{11}$ These executives

\footnotetext{
${ }^{1}$ C Mangen and M Magnan, '"Say on Pay": A Wolf in Sheep's Clothing?' (2012) The Academy of Management Perspectives 86.

2 S O'Byrne, 'Say on Pay: Is It Needed? Does It Work?' (2018) Journal of Applied Corporate Finance 30.

${ }^{3}$ C Mangen and M Magnan, '"Say on Pay": A Wolf in Sheep's Clothing?’ (2012) The Academy of Management Perspectives 86.

${ }^{4}$ Ibid.

5 S O'Byrne, 'Say on Pay: Is It Needed? Does It Work?' (2018) Journal of Applied Corporate Finance 30.

${ }^{6}$ Ibid.

${ }^{7}$ A L Bethune, 'An Efficient Say on Executive Pay: Shareholder Opt-in as a Solution to the Managerial Power Problem' (2011) Houston Law Review 587.

${ }^{8}$ Ibid.

${ }^{9}$ Ibid.

${ }^{10}$ S O'Byrne, 'Say on Pay: Is It Needed? Does It Work?' (2018) Journal of Applied Corporate Finance 30.

${ }^{11}$ A L Bethune, 'An Efficient Say on Executive Pay: Shareholder Opt-in as a Solution to the Managerial Power Problem' (2011) Houston
} 
have to consider how to reduce management risk and improve their performance in order to obtain higher compensation. The firm value and shareholder wealth are occasionally ignored. In this situation, the role of the board should be discussed.

\section{Directors Fail to Oversee the Adjustment of Executive Remuneration}

Directors, as members of the board, are the agents of shareholders in the company. They have a fiduciary duty to make the best use of the investment from shareholders and create greater interests for firms and shareholders. One of the obligations for directors is making executive compensation plans that provide efficient incentives for managers to improve company value and shareholder wealth. ${ }^{12}$ However, directors fail to oversee the adjustment of executive remuneration.

\subsection{Directors may Pursue Their Own Interests at the Expense of Shareholders}

The first reason is that members of the board may pursue their own interests at the expense of shareholders. For example, chief executive officers (CEO), as executive members, have the right to nominate members of the board. ${ }^{13}$ It is clear that executives could bring actual benefits to directors in some situations. When creating executive compensation plans, the board tends to consider the interests of executives instead of maximizing shareholder profits. Therefore, directors are more likely to improve the compensation of executives in order to obtain their own benefits.

\subsection{Directors may not Have Sufficient Incentives to Maximize Shareholder Wealth in the Process of Creating Executive Compensation}

In addition, directors have weak incentives to maximize shareholder wealth in the process of creating executive compensation. For example, directors' stock ownership is insufficient compared with that of the shareholders. ${ }^{14}$ In other words, a large proportion of their income comes from providing management for companies. Shareholders, especially big and powerful shareholders, could benefit from the successful governance of the firm. Hence, when directors adjust the executive remuneration, they do not have strong incentives to consider the real value of companies and pursue the interests of shareholders.

\subsection{Directors may not Take All Factors into Consideration When Creating Executive Compensation Plans}

Finally, the board may not take all factors into consideration when creating executive compensation plans. This is mainly due to the fact directors lack diversity. ${ }^{15}$ For example, it was reported that in 2010, five out of six directors of firms in the S\&P 500 were male. ${ }^{16}$ It is also argued that directors, especially those who participate in creating executive compensation plans, usually have strong professional backgrounds, including former roles as executives, lawyers, scholars and some other professionals ${ }^{17}$ From these two examples, it could be concluded that without diversity, directors tend to have similar ideas when they make decisions. Accordingly, it is difficult for them to take all factors into consideration to make the best executive remuneration plan.

For the three reasons mentioned above, it is apparent that directors perform poorly in overseeing the adjustment of executive compensation. The calls to introduce a new mechanism to improve the efficiency of executive compensation plans are rising. There is an increasing interest in income inequality and excessive executive compensation in particular. ${ }^{18}$ Excessive pay is defined in economics as when the remuneration exceeds the marginal revenue product. ${ }^{19}$ A new mechanism should focus on the relationship between executive remuneration and management performance. Specifically, if executives actually improve firm value and create profits for shareholders, they should be paid more. In contrast, if they perform poorly in management, they should not receive high compensation, let alone excessive pay. As the management of executives should be responsible for maximizing shareholder wealth, so shareholders should be involved in the process of adjusting executive compensation. If shareholders can participate in creating executive compensation plans, directors are more likely to do a better job.

\footnotetext{
Law Review 587.

${ }^{12}$ Ibid.

${ }^{13}$ Ibid.

${ }^{14}$ S O'Byrne, 'Say on Pay: Is It Needed? Does It Work?' (2018) Journal of Applied Corporate Finance 30.

15 C Mangen and M Magnan, '"Say on Pay": A Wolf in Sheep's Clothing?' (2012) The Academy of Management Perspectives 86.

${ }^{16}$ Ibid.

${ }^{17}$ Ibid.

${ }^{18}$ S HomRoy and R Simmon, 'Can Say On Pay Regulations Restrain CEO Pay? Evidence from Europe', Lancaster University.

${ }^{19}$ Ibid.
} 


\section{The Definition and a Brief History of 'Say on Pay' in the UK and US}

\subsection{The Definition of 'Say on Pay'}

'Say on Pay' is a corporate governance mechanism that allows shareholders to vote on executive remuneration reports. Shareholders can voice their views on executive compensation by voting in the annual general meeting of the corporation. ${ }^{20}$ Because directors fail to provide sufficient oversight, executives will occasionally be overpaid. Although both affirmative votes and dissenting votes from shareholders are not binding, they can provide the directors with suggestions regarding how to adjust the executive compensation. Therefore, 'Say on Pay' could be regarded as a kind of corporate practice to give shareholders more rights to express their views on executive compensation. ${ }^{21}$ Under this new mechanism, directors are more likely to create an efficient executive remuneration plan.

\subsection{A Brief History of 'Say on Pay' in the UK and the US}

The development of 'Say on Pay' in the UK occurred over a long period, during which a series of reforms were launched. Before the adoption of 'Say on Pay' in the UK, there were several private corporate-governance reforms in the 1990s. Public companies were requested to abide by a regulation which required the board to hold a meeting. In this annual meeting, whether to accept shareholder approval of executive compensation policies was to be discussed. ${ }^{22}$ However, although a large proportion of UK companies abided by this regulation, there was no decrease in executive compensation in this period. ${ }^{23}$ In 2002, as a response to this phenomenon, the British government revised the UK Companies Act. In this amendment, public companies were supposed to publish a Directors' Remuneration Report (DRR) annually. The details about executive compensation had to be included in the DRR, which was then submitted to an annual advisory vote of shareholders. ${ }^{24}$ Certainly, giving shareholders the legal right to voice their views towards executive compensation was a breakthrough attempt. Shareholders could engage more in the process of pay setting. In 2014 reforms, more detailed regulations were stipulated in the UK. Under these reforms, companies should hold a vote on remuneration policies every three years. These votes are binding. ${ }^{25}$ In addition, companies are required to vote on remuneration reports each year. These votes are nonbinding. ${ }^{26}$ Following these reforms, shareholders tend to be more active in the process of providing directors with opinions on executive compensation. In addition, the relationship between executive compensation and executive performance is paid greater attention in the UK. It is not only determined by directors but is also influenced by the suggestions from shareholders.

Since the British government adopted 'Say on Pay' in 2002, the Netherlands, Sweden, Norway, Denmark and some other countries have adopted this principle. ${ }^{27}$ In the US, the demand to enhance the relationship between executive compensation and company performance by allowing shareholders to express their views has led to legal reforms for about 20 years. ${ }^{28}$ From 1992, shareholders were allowed to provide suggestions regarding executive compensation and directors were required to organize all shareholders to vote on it. ${ }^{29}$ Especially during the 20072009 period, a series of pressures within the context of the financial crisis accelerated the establishment of 'Say on Pay' in the US. The first pressure was from society. A range of executive compensation scandals and the widespread debates that followed pushed the US government to give shareholders more rights in pay setting. ${ }^{30}$ It is undeniable that the interests of shareholders were emphasized in the US. The second pressure was political. It is argued that before the adoption of 'Say on Pay', the votes from shareholders not only provided recommendations concerning executive pay for directors, but also focused on other issues in the company. ${ }^{31}$ Obviously, previous

\footnotetext{
${ }^{20}$ G Lozano-Reina and G Sánchez-Marín, 'Say on pay and executive compensation: A systematic review and suggestions for developing the field’ (2019) Human Resource Management Review 2/2019.

${ }^{21}$ S O'Byrne, 'Say on Pay: Is It Needed? Does It Work?' (2018) Journal of Applied Corporate Finance 30.

${ }^{22}$ A L Bethune, 'An Efficient Say on Executive Pay: Shareholder Opt-in as a Solution to the Managerial Power Problem' (2011) Houston Law Review 587.

${ }^{23}$ Ibid.

${ }^{24}$ Ibid.

25 'Executive Rewards Paying for Success', Eighteenth Report of Session 2017-19, BEIS Committee.

${ }^{26}$ Ibid.

${ }^{27}$ A L Bethune, 'An Efficient Say on Executive Pay: Shareholder Opt-in as a Solution to the Managerial Power Problem' (2011) Houston Law Review 587.

${ }^{28}$ Ibid.

${ }^{29}$ Ibid.

${ }^{30}$ C Mangen and M Magnan, '"Say on Pay": A Wolf in Sheep's Clothing?' (2012) The Academy of Management Perspectives 86.

${ }^{31}$ Ibid.
} 
policies were not concentrated on the executive remuneration problem and the role of shareholders in pay setting. The third pressure was functional pressure. Giving shareholders more opportunities to express their opinions on executive compensation could help directors overcome the problem of lack of information. ${ }^{32}$ Directors could adjust the executive compensation according to the votes from shareholders. Based on these pressures, the DoddFrank Act mandating 'Say on Pay' for all public companies was established on $21^{\text {st }}$ July $2010 .{ }^{33}$ Companies are required to hold an advisory shareholder vote on the top five executives' compensation. At least every six years, shareholders must be allowed to hold a non-binding vote on the frequency of holding the 'Say on Pay' vote. ${ }^{34}$ Furthermore, the information about the relationship between executive compensation and company performance and some other details related to compensation should be disclosed. ${ }^{35}$ All companies have to abide by the regulations in the Dodd-Frank Act mandating 'Say on Pay'. ${ }^{36}$ The enactment of the Dodd-Frank Act mandating 'Say on Pay' gave shareholders in the US the legal right to express their views on executive remuneration.

Clearly, 'Say on Pay' developed over a long period in both the UK and the US. From initiating political rules to subsequent legal regulations, shareholders have more say in executive pay and this right was eventually enacted in related law. When directors create executive compensation plans, they are more likely to do a better job than before, as they can refer to shareholder voting results. However, whether 'Say on Pay' really plays a role in solving the problem of excessive executive remuneration in the UK and the US will be critically analysed in the following part.

\section{Arguments about the Effectiveness of 'Say on Pay' in Addressing the Problem of Excessive Executive Remuneration}

There is a debate about whether 'Say on Pay' has economic value in creating executive compensation plans. Some believe that shareholders have more influence on executive pay through voting, which tends to align executive compensation contracts with shareholder value and helps the board perform better. Others argue that this process is not necessary, because it increases company costs and decreases shareholder wealth. ${ }^{37}$ This part will discuss the role of 'Say on Pay' in solving the problem of excessive executive compensation using four arguments.

\subsection{Votes from Shareholders may not Affect the Decisions of Directors}

First, the question of whether directors will be influenced by shareholder voting results when they create executive compensation plans is relevant. The relationships among shareholders, directors and executives are one of the core topics in corporate law. In the past, directors made decisions on executive compensation independently. Under the 'Say on Pay' mechanism, shareholders can voice their opinions on executive compensation. Their voting could provide directors with some shareholder suggestions that could be taken into consideration when making executive compensation plans. Although company directors do not have much stock ownership, their compensation is related to the firm's wealth and shareholder value. ${ }^{38}$ In order to increase their pay, they tend to refer to shareholder voting and align with the interests of shareholders. However, it is argued that director pay plans are similar to executive pay plans, which are determined according to the firm's competitive pay policy. This kind of policy neglects directors' performance in the past. ${ }^{39}$ From this argument, it is clear that directors' pay is less likely to be influenced by their performance in past years. Whether their performance improves firm value has little impact on their compensation. Moreover, shareholders do not provide directors with adequate incentives to limit excessive executive compensation. ${ }^{40}$ Shareholders are investors of the company and can obtain dividends if the firm value improves. Hence, they have strong incentives to oversee the operation of the company. However, directors provide labour to make profits for shareholders and may not obtain a larger number of rewards from the improvement of firm value. According to data analysis, at a low level of 'Say on Pay' approval, the board does not take action to

\footnotetext{
${ }^{32}$ Ibid.

${ }_{33}$ A L Bethune, 'An Efficient Say on Executive Pay: Shareholder Opt-in as a Solution to the Managerial Power Problem' (2011) Houston Law Review 587.

${ }^{34}$ Ibid.

${ }^{35}$ Ibid.

${ }^{36}$ Ibid.

${ }^{37} \mathrm{~K}$ Brunarski, T Campbell and Y Harman, 'Evidence on the outcome of Say-On-Pay votes: How managers, directors, and shareholders respond' (2015) Journal of Corporate Finance 132.

${ }^{38}$ S O'Byrne, 'Say on Pay: Is It Needed? Does It Work?' (2018) Journal of Applied Corporate Finance 30.

39 Ibid.

${ }^{40} \mathrm{~K}$ Brunarski, T Campbell and Y Harman, 'Evidence on the outcome of Say-On-Pay votes: How managers, directors, and shareholders respond' (2015) Journal of Corporate Finance 132.
} 
improve company value. ${ }^{41}$ It is obvious that directors have fewer incentives to reduce excessive executive compensation and contribute more to shareholder wealth. Overall, although the income of directors is affected by firm value to some extent and they have obligations to limit excessive executive remuneration, directors' pay has little connection with past performance and directors do not have enough incentives to limit excessive executive compensation.

\subsection{There Is no Overwhelming or Sufficient Evidence to Support the Contention That Excessive Executive Remuneration Is Limited under 'Say on Pay'}

Secondly, even if directors accept the suggestions from shareholders, there is little evidence that excessive executive compensation is limited under the 'Say on Pay' mechanism. A number of surveys have concentrated on how shareholder voting results influence the adjustment of executive compensation. In an investigation regarding the impact of 'Say on Pay' on 2010 executive pay, influenced companies reduced executive pay and made it more related to performance before the 2011 shareholders' vote. ${ }^{42}$ This investigation found that directors tended to reduce executive compensation in order to obtain the high approval of shareholders during the next vote. In addition, the change in shareholders' dissenting votes positively correlated with the change in executive compensation. It is argued that dissenting votes from shareholders would decrease if executive compensation were to be reduced. On the contrary, the dissenting votes would increase if executive remuneration were to rise ${ }^{43}$ It seems that directors are more likely to be influenced by shareholders' opinions and adjust executive remuneration. In addition, there is evidence showing that after the adoption of 'Say on Pay', the executive remuneration achieves shareholder satisfaction. For example, the DRR receives less than $10 \%$ of dissenting votes from shareholders. ${ }^{44}$ It is evident that shareholders are satisfied with directors' work. However, most surveys usually concentrated on a certain year or a limited period and could not explore the long-term impact of 'Say on Pay'. There is no evidence supporting a long-term influence of 'Say on pay' on the reduction of excessive executive compensation. ${ }^{45}$ Furthermore, the influence of 'Say on Pay' is not large, consistent or clear from present evidence. ${ }^{46}$ As a result, it cannot be concluded from previous studies that 'Say on Pay' plays a role in providing directors with effective suggestions and improving the quality of executive compensation plans. It also could not be demonstrated that the problem of excessive executive pay has been efficiently relieved. Worse, the process of voting could only be regarded as a kind of remedial measure. Excessive executive compensation often happens before advisory shareholder voting. ${ }^{47}$ It has no influence on previous excessive executive pay. Furthermore, whether 'Say on Pay' has a material influence on executive remuneration is unclear. For instance, limited evidence indicates that the advisory shareholder voting has a material impact on reducing executive compensation. ${ }^{48}$ Another example shows that executive remuneration reduces when performance is poor. The reduction may not be related to 'Say on Pay'. ${ }^{49}$ The reason behind the reduction of executive remuneration may relate to social pressure. It is argued that there is an increasing concern about income inequality. ${ }^{50}$ In order to address negative press, companies choose to take action to solve this problem. As such, although directors are likely to take shareholder voting results into consideration and achieve the satisfaction of shareholders, it cannot be concluded from previous studies that 'Say on Pay' has a long-term and material effect on relieving the problem of excessive executive pay. The worst presumption is that advisory shareholder voting does not address what has already occurred.

\subsection{Shareholder Voting Is of Poor Quality and Non-Binding}

Thirdly, although 'Say on Pay' influences directors' decisions on executive compensation plans, shareholder voting is non-binding and sometimes of poor quality. As a new mechanism, 'Say on Pay' undeniably plays an important role in allowing shareholders' attitudes towards existing executive remuneration for directors to be expressed.

\footnotetext{
${ }^{41}$ Ibid.

42 S Balsam, J Boone, H Liu and J Yin, 'The impact of say-on-pay on executive compensation' (2016) Journal of Accounting and Public Policy 162.

${ }^{43}$ Ibid.

${ }^{44}$ Ibid.

${ }^{45} \mathrm{~K}$ Brunarski, T Campbell and Y Harman, 'Evidence on the outcome of Say-On-Pay votes: How managers, directors, and shareholders respond' (2015) Journal of Corporate Finance 132.

${ }^{46}$ S HomRoy and R Simmon, 'Can Say On Pay Regulations Restrain CEO Pay? Evidence from Europe', Lancaster University.

${ }^{47}$ K Brunarski, T Campbell and Y Harman, 'Evidence on the outcome of Say-On-Pay votes: How managers, directors, and shareholders respond' (2015) Journal of Corporate Finance 132.

${ }^{48}$ S Balsam, J Boone, H Liu and J Yin, 'The impact of say-on-pay on executive compensation' (2016) Journal of Accounting and Public Policy 162.

${ }^{49}$ Ibid.

${ }^{50}$ S HomRoy and R Simmon, 'Can Say On Pay Regulations Restrain CEO Pay? Evidence from Europe’, Lancaster University.
} 
Since shareholders are the investors of companies, this mechanism enhances the engagement of shareholders and enriches directors' information. ${ }^{51}$ When directors make decisions, they will tend to do a better job and increase profits for shareholders. In addition, directors' decisions can be affected by powerful CEOs. If the board is controlled by CEOs, directors are more likely to improve executive compensation to cater to executives. ${ }^{52}$ The reason for this phenomenon is that CEOs prefer to improve their remuneration, which leads to extremely high executive remuneration. From this analysis, advisory shareholder voting is beneficial to relieve the intense relationship between powerful CEOs and directors and contribute to reducing excessive executive compensation. Furthermore, 'Say on Pay' is useful in corporate governance. It represents a breakthrough in efficiently relieving the relationship between the owners and managers of companies. ${ }^{53}$ Shareholders and directors could supervise each other, forming a virtuous circle in company operation. However, some argue that the shareholder voting is not of a high quality. The first reason is that shareholders only focus on the short-term performance of executives. ${ }^{54}$ After analysing a short-term performance, they choose to approve or dispute an executive compensation plan. Another reason is that shareholders are not well-informed. ${ }^{55}$ Shareholders are not responsible for the daily issues of the company, so they have little insight into the performance of executives. Sometimes they may rely on biased information. ${ }^{56}$ For these reasons, shareholders are less likely to cast quality votes. It is unfair for executives to be judged by shareholders. In addition, majority shareholders have more say in executive compensation. Under 'Say on Pay', majority shareholders have more power. These big shareholders tend to pursue their own interests instead of considering the long-term development of the company. If they have conflicting interests with small shareholders, the interests of minority shareholders will be sacrificed. ${ }^{57}$ As a result, the attitudes towards executive compensation reflect those of majority shareholders. Finally, the advisory shareholder vote is non-binding and directors could choose to neglect shareholder votes when making executive compensation plans. ${ }^{58}$ The first reason why directors are less likely to be changed by shareholders is that they believe they are better informed and familiar with executive work. ${ }^{59}$ Another reason is that directors have a strong connection with managers, who support their daily work. ${ }^{60}$ Based on these two reasons, directors tend to ignore shareholder voting. If directors refuse to take shareholder voting results into consideration, the votes seem useless. ${ }^{61}$ Therefore, non-binding votes are limited in their ability to change directors' opinions. It is clear that advisory shareholder voting enables the expression of shareholders' attitudes and limits the CEOs' power, which is beneficial for corporate governance. However, shareholders' votes are non-binding and sometimes lack quality.

\subsection{Whether Shareholders Are Influenced by Professional Suggestions from Institutional Shareholder Services Is not Clear}

Finally, before shareholders vote on executive compensation, Institutional Shareholder Services provides them with recommendations. There is a debate about whether recommendations from Institutional Shareholder Services help shareholders efficiently vote on executive remuneration plans. Proponents believe that Institutional Shareholder Services provides shareholders with useful advice. It is argued that there is a connection between advice from Institutional Shareholder Services and shareholder voting results. ${ }^{62}$ The greater the approval from Institutional Shareholder Services, the less likely shareholders are to vote against executive compensation. It has also been demonstrated that some shareholders simply rely on recommendations to vote on executive compensation. The advice from Institutional Shareholder Services has a strong influence on shareholder voting

\footnotetext{
${ }^{51}$ C Mangen and M Magnan, '"Say on Pay": A Wolf in Sheep's Clothing?' (2012) The Academy of Management Perspectives 86.

52 Ibid.

${ }^{53}$ M Kimbro and D Xu, 'Shareholders have a say in executive compensation: Evidence from say-on-pay in the United States' (2016) Journal of Accounting and Public Policy 19.

${ }^{54}$ S O'Byrne, 'Say on Pay: Is It Needed? Does It Work?' (2018) Journal of Applied Corporate Finance 30.

${ }^{55}$ Ibid.

${ }^{56}$ C Mangen and M Magnan, 'Say on Pay": A Wolf in Sheep's Clothing?' (2012) The Academy of Management Perspectives 86.

${ }^{57}$ Ibid.

${ }^{58}$ S Balsam, J Boone, H Liu and J Yin, ‘The impact of say-on-pay on executive compensation' (2016) Journal of Accounting and Public Policy 162.

${ }^{59}$ K Brunarski, T Campbell and Y Harman, 'Evidence on the outcome of Say-On-Pay votes: How managers, directors, and shareholders respond' (2015) Journal of Corporate Finance 132.

${ }^{60}$ Ibid.

${ }^{61}$ C Mangen and M Magnan, '"Say on Pay": A Wolf in Sheep's Clothing?' (2012) The Academy of Management Perspectives 86.

${ }^{62} \mathrm{~S}$ Balsam, J Boone, H Liu and J Yin, 'The impact of say-on-pay on executive compensation' (2016) Journal of Accounting and Public Policy 162.
} 
results. ${ }^{63}$ Therefore, professional services to some extent help shareholders vote on executive compensation plans efficiently. However, opponents state that suggestions from Institutional Shareholder Services are not helpful to shareholders when voting on executive compensation plans. It is argued that there is only a weak relationship between advice from Institutional Shareholder Services and shareholder voting results. Advice does not determine the voting results. ${ }^{64}$ In some instances, shareholders do not accept professional suggestions from Institutional Shareholder Services. Accordingly, shareholders' votes on executive remuneration lack a degree of efficiency. Overall, whether shareholders can receive professional suggestions from Institutional Shareholder Services influences the quality of shareholder voting on executive compensation.

There is a debate about whether the advisory shareholder vote on executive remuneration report plays a meaningful role in solving the excessive executive remuneration problem. Some scholars view it as a successful attempt in corporate law, which gives shareholders opportunities to pursue their interests. Other academics argue that this new mechanism cannot produce an ideal effect. The author of this essay believes that 'Say on Pay' lacks efficiency in reducing excessive executive compensation for four reasons. First, directors have weak incentives to align with shareholder wealth. Second, there is little evidence that excessive executive compensation is limited in the long term through the mechanism of 'Say on Pay'. Third, shareholder voting is of poor quality and non-binding. Finally, whether shareholders are influenced by professional suggestions from Institutional Shareholder Services is not clear. For these reasons, it seems that 'Say on Pay' is useless in solving the problem of excessive executive remuneration. However, existing investigations on the influence of 'Say on Pay' have some limitations. First, these investigations were unable to analyse all articles related to this topic. ${ }^{65}$ Second, some factors may be ignored in these investigations. ${ }^{66}$ Finally, the effect of existing legal rules cannot be excluded ${ }^{67}$ Consequently, based on existing investigations, the conclusion of this essay has value only as a reference.

\section{Conclusion}

In conclusion, 'Say on Pay' represents a breakthrough in solving excessive executive compensation in corporate law. It underwent a long period of development in the UK and the US. Since there is a mutual interest relationship between directors and executives and directors have weak incentives to pursue benefits for shareholders, they fail to limit excessive executive remuneration. Moreover, directors cannot take all factors into consideration when they make decisions. As a new mechanism, 'Say on Pay' certainly allows shareholders to provide advice to directors by voting on the executive remuneration report, which tends to help directors do a better job. However, the material influence of 'Say on Pay' is questioned by scholars, for four main reasons. The first reason is that votes from shareholders may not affect the decisions of directors. Then, even if directors are influenced by shareholder voting results, there is no overwhelming or sufficient evidence to support the contention that excessive executive remuneration is limited under 'Say on Pay'. Furthermore, shareholders tend to focus on the short-term performance of executives and lack information about executives' daily performance, which leads to poor quality votes. The voting is also non-binding to directors and can therefore be ignored when they make the executive remuneration report. The last rationale is the lack of clarity regarding whether professional recommendations from Institutional Shareholder Services have a material influence on shareholders. As a result, 'Say on Pay' is less likely to contribute to the process of determining executive compensation. As such, the problem of excessive executive remuneration cannot be relieved under this new mechanism. However, we cannot expect to solve the problem through only one simple mechanism. Many aspects of 'Say on Pay' could also be improved. In the future, shareholders should be required to take advice from professional institutions into consideration before voting on executive remuneration reports. The voting results should be binding to directors. Through these improvements of 'Say on Pay' and the probable development of another mechanism, the problem of excessive executive remuneration is likely to be relieved in the coming years.

\section{Acknowledgments}

This essay received help from professors at law school, the University of Edinburgh. Dr Remus Valsan, who worked as a senior lecturer in corporate law, his main research interests lie in the fields of fiduciary law, comparative corporate law and governance, law and economics, and trust law. Dr Jonathan Hardman, who was a

\footnotetext{
${ }^{63}$ M Kimbro and D Xu, 'Shareholders have a say in executive compensation: Evidence from say-on-pay in the United States' (2016) Journal of Accounting and Public Policy 19.

${ }^{64}$ Ibid.

${ }^{65}$ G Lozano-Reina and G Sánchez-Marín, 'Say on pay and executive compensation: A systematic review and suggestions for developing the field' (2019) Human Resource Management Review 2/2019.

${ }^{66}$ Ibid.

${ }^{67}$ Ibid.
} 
solicitor in private practice for 10 years before starting at the Law School, His research is conducted across a broad range of commercial law (particularly rights in security) and company law (particularly the law of private companies). Most of his research has a law and economics methodology, which he has applied to a broad range of different subject matters. At the beginning, they encouraged me to spend more time reading primary sources, which were considerably useful for researching. After completing my draft, they provided me with a series of constructive suggestions. The revision of this essay experienced a long term and thanks a lot for their patience.

\section{References}

'Executive Rewards Paying for Success', Eighteenth Report of Session 2017-19, BEIS Committee.

Balsam, S., Boone, J., Liu, H., \& Yin, J. (2016). The impact of say-on-pay on executive compensation. Journal of Accounting and Public Policy, 162. https://doi.org/10.1016/j.jaccpubpol.2015.11.004

Bethune, A. L. (2011). An Efficient Say on Executive Pay: Shareholder Opt-in as a Solution to the Managerial Power Problem. Houston Law Review, 587.

Brunarski, K., Campbell, T., \& Harman, Y. (2015). Evidence on the outcome of Say-On-Pay votes: How managers, directors, and shareholders respond. Journal of Corporate Finance, 132. https://doi.org/10.1016/j.jcorpfin.2014.12.007

Companies Act 2006

Ferri, F., \& Maber, D. (2013). Say on Pay Votes and CEO Compensation: Evidence from the UK. Review of Finance, 527. https://doi.org/10.1093/rof/rfs003

HomRoy, S., \& Simmon, R. (n.d.). Can Say On Pay Regulations Restrain CEO Pay? Evidence from Europe. Lancaster University.

Kimbro, M., \& Xu, D. (2016). Shareholders have a say in executive compensation: Evidence from say-on-pay in the United States. Journal of Accounting and Public Policy, 19. https://doi.org/10.1016/j.jaccpubpol.2015.08.003

Lozano-Reina, G., \& Sánchez-Marín, G. (2019). Say on pay and executive compensation: A systematic review and suggestions for developing the field. Human Resource Management Review, 2. https://doi.org/10.1016/j.hrmr.2019.01.004

Mangen, C., \& Magnan, M. (2012). "Say on Pay": A Wolf in Sheep's Clothing? The Academy of Management Perspectives, 86. https://doi.org/10.5465/amp.2010.0098

O'Byrne, S. (2018). Say on Pay: Is It Needed? Does It Work? Journal of Applied Corporate Finance, 30.

UK Corporate Governance Code 2018.

\section{Copyrights}

Copyright for this article is retained by the author(s), with first publication rights granted to the journal.

This is an open-access article distributed under the terms and conditions of the Creative Commons Attribution license (http://creativecommons.org/licenses/by/4.0/). 